\title{
MEMBANGUN PARADIGMA ILMIAH PADA SISTEM PENDIDIKAN
}

\section{ISLAM}

\author{
Oleh \\ Muhyiddin Zainul Arifin \\ STMIK Bahrul 'Ulum Tambakberas Jombang \\ Email: muhyiddinarifin@yahoo.com
}

\begin{abstract}
Abstrak
Peran pendidikan Islam mestinya bukan hanya "dipahami dalam konteks mikro, kepentingan anak didik yang dilayani melalui proses interaksi pendidikan, melainkan juga dalam konteks makro, yaitu kepentingan masyarakat yang dalam hal ini termasuk masyarakat bangsa, negara dan bahkan juga kemanusiaan pada umumnya, sehingga pendidikan Islam integratif antara proses belajar di sekolah dengan belajar di masyarakat.

Sistem pendidikan pondok pesantren perlu juga system yang menganut paradigm ilmiah, dalam arti membentuk pandangan bagi santri sebagai peserta mampu mengembangkan ilmu yang diperolehnya ke dalam kehidupan masyarakat, baik dalam bentuk tindakan nyata maupun dalam bentuk sumbangan pikiran. Sumbangan pikiran yang dimaksud berupa karya-karya tulis yang mengandung gagasan dan ide yang sangat berharga untuk pengembangan ilmu-ilmu islam khususnya. Dengan demikian perlu menanamkan pola pikir santri yang tidak hanya belajar tapi santri juga mampu menghasilkan karya-karya besar dalam bentuk tulisan-tulisan ilmiah yang bisa dibaca dan menjadi referensi penting bagi perkembangan ilmu pengetahuan islam

Kata kunci: Sistem pendidikan islam, paradigm ilmiah, pondok pesantren
\end{abstract}

\section{PENDAHULUAN}

\section{Latar belakang penelitian}

Proses pendidikan yang berakar dari kebudayaan, berbeda dengan praktek pendidikan yang terjadi dewasa ini yang cenderung mengalienasikan proses pendidikan dari kebudayaan. Perlu suatu perubahan paradigma (paradigma shift) dari pendidikan untuk menghadapi proses globalisasi dan menata kembali kehidupan masyarakat Indonesia (Sanaky, Hujair.A.H, 2010). Cita-cita era reformasi tidak lain ialah membangun suatu masyarakat madani Indonesia [H.A.R. Tilaar, 1999:168], oleh karena itu, arah perubahan paradigma ilmiah pendidikan Islam diarahkan untuk terbentuknya masyarakat madani Indonesia tersebut.

Sekarang di Indonesia ada ribuan lembaga pendidikan Islam terletak diseluruh nusantara dan dikenal sebagai dayah dan rangkang di Aceh, surau di Sumatra Barat, dan pondok pesantren di Jawa (Azra, 2001:70). Pondok pesantren di Jawa itu membentuk banyak macam-macam jenis. Perbedaan jenis-jenis pondok pesantren di Jawa dapat 
dilihat dari segi ilmu yang diajarkan, jumlah santri, pola kepemimpinan atau perkembangan ilmu teknologi. Namun demikian, ada unsur-unsur pokok pesantren yang harus dimiliki setiap pondok pesantren. (Hasyim, 1998:39) Unsur-unsur pokok pesantren, yaitu kyai. masjid, santri, pondok dan kitab Islam klasik (atau kitab kuning), adalah elemen unik yang membedakan sistem pendidikan pesantren dengan lembaga pendidikan lainnya.

Peran pendidikan Islam mestinya bukan hanya "dipahami dalam konteks mikro ,kepentingan anak didik yang dilayani melalui proses interaksi pendidikan, melainkan juga dalam konteks makro, yaitu kepentingan masyarakat yang dalam hal ini termasuk masyarakat bangsa, negara dan bahkan juga kemanusiaan pada umumnya" [ Fasli Jalal, 2001:16-17.], sehingga pendidikan Islam integratif antara proses belajar di sekolah dengan belajar di masyarakat [learning society]. Brubacher dalam bukunya, Modern Philosophies of Education [1978], menyatakan hubungan pendidikan dengan masyarakat mencakup hubungan pendidikan dengan perubahan sosial, tatanan ekonomi, politik dan negara, karena pendidikan itu terjadi di masyarakat, dengan sumber daya masyarakat, dan untuk masyarakat, maka pendidikan dituntut untuk mampu memperhitungkan dan melakukan antisipasi terhadap perkembangan sosial, ekonomi, politik dan kenegaraan secara simultan. Sedangkan, secara mikro pendidikan senantiasa memperhitungkan individualitas atau karakteristik perbedaan antara individu peserta didik [ Fasli Jalal, 2001: 16], dalam kerangka interaksi proses belajar.

Pondok pesantren adalah lembaga pendidikan Islam yang diperkenalkan di Jawa sekitar 500 tahun yang lalu. Sejak saat itu, lembaga pesantren tersebut telah mengalami banyak perubahan dan memainkan berbagai macam peran dalam masyarakat Indonesia. Pendidikan pondok pesantren yang menggunakan sistem klasikal dan non-klasikal untuk memberikan pendidikan dan pengajaran agama Islam tidak kalah pentingnya dengan pendidikan formal lainnya.

Sistem pendidikan pondok pesantren perlu juga system yang menganut paradigm ilmiah, dalam arti membentuk pandangan bagi santri sebagai peserta mampu mengembangkan ilmu yang diperolehnya ke dalam kehidupan masyarakat, baik dalam bentuk tindakan nyata maupun dalam bentuk sumbangan pikiran. Sumbangan pikiran yang dimaksud berupa karya-karya tulis yang mengandung gagasan dan ide yang sangat berharga untuk pengembangan ilmu-ilmu islam khususnya. Dengan demikian perlu menanamkan pola pikir santri yang tidak hanya belajar tapi santri juga mampu menghasilkan karya-karya besar dalam bentuk tulisan-tulisan ilmiah yang bisa dibaca dan menjadi referensi penting bagi perkembangan ilmu pengetahuan islam. 


\section{Rumusan Masalah}

Berdasarkan maslah di atas dalam rangka membangun paradigm ilmiah dalam system pendidikan pondok pesantren, maka dirumuskan sebagai berikut:

a. Apakah yang dimaksud dengan paradigm ilmiah

b. Bagaimana membangun paradigm ilmiah

c. Bagiaman bentuk system dan metode pendidikan islam

d. Bagimana membangun paradigm ilmiah dalam system pendidikan islam

\section{Batasan Masalah}

Berdasarkan berbagai rumusan masalah di atas maka pada penelitian ini akan dibahas mengenai paradigm ilmiah pada system pendidikan pada pondok pesantren.

\section{Signifikansi Penelitian}

Hasil penelitian ini diharapkan dapat memberikan manfaat sebagai berikut:

\section{a. Manfaat keilmuan}

Hasil penelitian ini diharapkan bermanfaat bagi pengembangan teori-teori dalam membangun system pendidikan islam pada umumnya dan system pendidikan di pondok pesantren pada khususnya.

\section{b. Manfaat praktis.}

Hasil penelitian ini diharapkan dapat membentuk pola pikir santri agar mampu menghasilkan karya-karya ilmiah yang dapat memberikan sumbangan pikiran untuk kemajuan ilmu pengetahuan islam secara lebih luas.

\section{Kajian Riset Sebelumnya}

Mayra Walsh (2002) dalam penelitiannya yang berjudul “ Pondok Pesantren dan Ajaran Golongan Islam Esaktrim, studi Kasus pada pondok Pesantren Modern Putri 'Darur Ridwan Parangharjo banyuwangi', bahwa system pendidikan pondok pesantren memuat kurikulum yang berbeda-beda tergantung kepada kyainya, sehingga perlu observasi dan evaluasi system pendidikan. Dalam penelitiannya tidak menjelaskan secara tegas system pendidikan yang dianut pada pondok pesantren sehingga walaupun system pendidikankanya berbeda antar pondok pesantren namun sebenarnya sebenarnya punya system pendidikan yang sama.

Kutbi, (2010) dalam makalah metode penelitian pendidikan islam menyatakan bahwadalam pendidikan islam memiliki banyak metode, sehingga permasalahan pendidikan yang berbeda-beda perlu dilakukan dengan pendekatan metode pendidikan yang berbeda-beda pula yang disesuaikan dengan metode mana yang mudah dipahami 
oleh peserta didik. Namun dalam penjelasanya tidak menyebutkan tentang terbentuknya paradigm peserta didik terhadap berbagai pendekatan metode pendidikan yang ada, sehingga sasaran pendidikan walaupun bias menformulasikan metode pendidikan tidak bisa menyeluruh untuk mencapai tujuan membentuk manusia yang terdidik.

Berdasarkan kajian studi dari penelitian di atas maka perlu dilakukan pendekatan untuk membangun pola piker santri secara ilmiah, sehingga paradigm berpikir ilmiah memberikan modal bagi para santri untuk menuangkan semua ilmu yang diperolehnya selama mengikuti pendidikan di pesantren ke dalam wujud karya ilmiah yang memberikan perkemgangan dan kemajuan ilmu pengetahuan islam.

\section{Metodologi Penelitian}

Metode penelitian yang digunakan adalah metode kualitatif dengan kajian teoriteori yang relevan dengan topic penelitian. Kajian teori diharapkan akan terbentuk konsep paradigma ilmiah system pendidikan islam khususnya yang dikembangkan dalam pondok pesantren.

\section{TINJAUAN TOERI}

\section{Pengertian Paradigma Ilmiah}

Sebelum "paradigma" menjadi sebuah konsep yang populer, para ilmuwan telah menggunakan beberapa konsep lain dengan makna yang kurang lebih sama, yakni: kerangka teoritis (theoretical framework), kerangka konseptual (conceptual framework), kerangka pemikiran (frame of thinking), orientasi teoritis (theoretical orientation), sudut pandang (perspective), atau pendekatan (approach).

Paradigma adalah kumpulan tata nilai yang membentuk pola pikir seseorang sebagai titik tolak pandangannya sehingga akan membentuk citra subyektif seseorangmengenai realita - dan akhimya akan menentukan bagaimana seseorang menanggapi realita itu. Pengertian paradigm diperkenalkan oleh Thomas Kuhn dalam The Structure of Scientific Revolution (1962), yang menyatakan bahwa ilmu pengetahuan bukan berkembangan secara kumulatif, sebagaimana banyak diyakini oleh para ilmuwan pada waktu itu, tetapi terjadi secara revolusi. Paradigma diartikan sebagai pola atau model atau cara pandang terhadap suatu persoalan yang di dalamnya terdapat sejumlah asumsi tertentu, teori tertentu, metode tertentu dan pemecahan masalah tertentu.

Pemikir lain seperti Patton (1975) mendefinisikan pengertian paradigma hampir sama dengan Khun, yaitu sebagai "a world view, a general perspective, a way of breaking down of the complexity of the real world [suatu pandangan dunia, suatu cara pandang umum, atau suatu cara untuk menguraikan kompleksitas dunia nyata]." Kemudian Robert Friedrichs (1970) mempertegas definisi tersebut sebagai suatu pandangan yang mendasar dari suatu disiplin ilmu tentang apa yang menjadi pokok persoalan yang semestinya 
dipelajari. Pengertian lain dikemukakan oleh George Ritzer (1980), dengan menyatakan paradigma sebagai pandangan yang mendasar dari para ilmuan tentang apa yang menjadi pokok persoalan yang semestinya dipelajari oleh salah satu cabang/disiplin ilmu pengetahuan.

\section{Membangun Paradigma Ilmiah}

Membangun paradigm diartikan :

\section{Sebagai system}

Yaitu terdapat tiga (3) unsur yaitu unsur masukan (inpu), unsur proses dan unsur keluaran (output).

\begin{tabular}{|c|c|c|}
\hline \multirow{4}{*}{$\begin{array}{l}\text { Unsur masukan (input): } \\
\text { Meliputi sumber daya yang } \\
\text { digunakan baik manusia, } \\
\text { alam, budaya, lembaga } \\
\text { kemasyarakatan, nilai-nilai } \\
\text { yang ingin dicapai; }\end{array}$} & & \\
\hline & Unsur Proses: & \\
\hline & & $\begin{array}{l}\text { Unsur keluaran } \\
\text { (output) }\end{array}$ \\
\hline & $\begin{array}{l}\text { Mencakup kompetensi } \\
\text { organisasi dan manajemen }\end{array}$ & $\begin{array}{l}\text { Baik berupa fisik } \\
\text { maupun non fisik }\end{array}$ \\
\hline
\end{tabular}

Gambar 1. Unsur-unsur pembentuk system yang membangun paradigm ilmiah.

Membangun paradigm ilmiah dalam system pendidikan pondok pesantren sebagai system yang memuat system input, proses dan output, dapat dijelaskan sebagai berikut:

a. Sistem input meliputi sumberdaya yang terlibat dalam pelaksanaan pendidikan pondok pesantren yang mencakup sumber daya manusia serta unsure-unsur yang ada pada pondok pesantren seperti kyai selaku pimpinan, masjid, santri, pondok dan kitab-kitab islam klasik.

b. Sistem proses sebagai mekanisme pembelajaran yang melibatkan kompetensi organisasi dan manajemen sehingga proses pembelajaran berjalan efektif, efisien dan berkualitas.

c. Sistem output, merupakan keluaran yang diharapkan dan memiliki keunggulankeunggulan kompetitif.

\section{Sebagai Metode}

Membangun paradigm sebagai orientasi pada upaya mencapai peningkatan kualitas hidup dan kesejahteraan yang didukung oleh pengorganisasi dan partisipasi masyarakat sebagai subyek pengguna.

Orientasi Pemikiran Ilmiah ditujukan pada upaya mewujudkan dan peningkatan pendidikan ilmiah serta pengembangan yang berpusat pada santri (student centered development) dan berorientasi pada pemberdayaan santri (student empowerment) agar 
dapat menjadi aktor pembangunan pendidikan ilmiah sehingga dapat menumbuhkan partisipasi santri dalam pembangunan, kemandirian dan etos kerja. Fokus perhatian dari membangun paradigma yang berpusat pada santri ini (student centered development paradigm) ini adalah perkembangan manusia (human-growth), kesejahteraan (wellbeing), keadilan (equity) dan berkelanjutan (sustainability). Dominasi pemikiran dalam paradigma ini adalah keseimbangan ekologi manusia (balanced human ecology), sumber pembangunannya adalah informasi dan prakarsa yang kreatif dengan tujuan utama adalah aktualisasi optimal dari potensi manusia (diadaptasi dari Korten, 1984:300 dalam Tjokrowinoto,1999:218).

Dalam proses membangun paradigm ilmiah santri dibangun dalam proses:

1. Pelayanan santri (student service)

2. Pembelajaran santri (student learning)

3. Pemberdayaan (empowerment)

4. Kemampuan (capacity);

5. Kelembagaan (institutional building).

\section{Sistem pendidikan Islam}

Beberapa ahli pendidikan di Barat yang memberikan arti pendidikan sebagai proses antara lain: Menurut Mortimer J. Adler mengartikan pendidikan adalah proses dengan mana semua kemampuan manusia (bakat dan kemampuan yang diperoleh) yang dapat dipengaruhi oleh pembiasaan, disempurnakan dengan kebiasaan-kebiasaan yang baik melalui sarana yang secara artistik dibuat dan dipakai oleh siapapun untuk membantu orang lain atau dirinya sendiri mencapai tujuan yang ditetapkan yaitu kebiasaan yang baik.

Menurut William Mc Gucken, SJ, seorang tokoh pendidikan Katolik berpendapat bahwa pendidikan diartikan oleh ahli Scholaktik, sebagai suatu perkembangan dan kelengkapan dari kemampuan-kemampuan manusia baik moral, intelektual, maupun jasmaniah yang diorganisasikan, dengan atau untuk kepentingan individual atau sosial dan diarahkan kepada kegiatan-kegiatan yang bersatu dengan Penciptanya sebagai tujuan akhir (Arifin, 1987)

Menurut Prof. Sugarda Purbakawaca, dalam "Ensiklopedi Pendidikan"nya, memberikan pengertian pendidikan, sebagai berikut: "Pendidikan dalam arti luas meliputi semua perbuatan dan usaha dari generasi tua untuk mengalihkan pengetahuannya, pengalamannya, kecakapannya serta ketrampilannya (orang menamakan ini juga "mengalihkan" kebudayaan, dalam bahasa Belanda: Cultuurover dracht) kepada generasi muda sebagai usaha menyiapkannya agar dapat memenuhi fungsi hidupnya baik jasmani maupun rohani."(Tadjab, 1984) 
Setelah membahas Pendidikan selanjutnya kita akan memaparkan tentang pendidikan Islam. Berikut ini adalah beberapa pengertian Pendidikan Islam secara terminologi yang diformulasikan oleh para ahli Pendidikan Islam, diantaranya adalah:

a. Menurut al-Syaibaniy mengemukakan bahwa pendidikan Islam adalah proses mengubah tingkah laku individu peserta didik pada kehidupan pribadi, masyarakat, dan alam sekitarnya. Proses tersebut dilakukan dengan cara pendidikan dan pengajaran sebagai suatu aktifitas asasi dan profesi diantara sekian banyak profesi asasi dalam masyarakat.

b. Menurut Muhammad Fadhil al-Jamaly, mendefinisikan pendidikan Islam sebagai upaya mengembangkan, mendorong serta mengajak peserta didik hidup lebih dinamis dengan berdasarkan nilai-nilai yang tinggi dan kehidupan yang mulia. Dengan proses tersebut, diharapkan bisa membentuk pribadi peserta didik yang lebih sempurna, baik yang berkaitan dengan potensi akal, perasaan, maupun perbuatannya.

c. Ahmad D. Marimba mengemukakan bahwa pendidikan Islam adalah bimbingan atau pimpinan secara sadar oleh pendidik terhadap perkembangan jasmani dan rohani peserta didik menuju terbentuknya kepribadiannya yang utama (insan kamil)

d. Ahmad Tafsir mendefinisikan Pendidikan Islam sebagai bimbingan yang diberikan oleh seseorang, agar ia berkembang secara maksimal sesuai dengan ajaran Islam. (Nizar, H. S., 2002).

Dari batasan diatas, dapat disimpulkan bahwa pendidikan Islam adalah suatu sistem yang memungkinkan seseorang (peserta didik) dapat mengarahkan kehidupannya sesuai dengan ideologi Islam. Melalui pendekatan ini, ia akan dapat dengan mudah membentuk kehidupan dirinya sesuai dengan nilai-nilai ajaran Islam yang diyakininya.

\section{Metode Pendidikan Islam}

Dari beberapa pengertian yang diformulasikan oleh para pakar diatas tentang pengertian Metode dan Pendidikan Islam. Kita dapat menyimpulkan tentang pengertian Metode Pendidikan. Seperti yang dikemukakan oleh al-Syaibaniy yaitu, segala segi kegiatan yang terarah yang dikerjakan oleh guru dalam rangka kemestian-kemestian mata pelajaran yang diajarkannya, ciri-ciri perkembangan peserta didiknya, dan suasana alam sekitarnya dan tujuan membimbing peserta didik untuk mencapai proses belajar yang diinginkan dan perubahan yang dikehendaki pada tingkah laku mereka (Omar, M., 1979).

Ahmad Tafsir secara umum membatasi bahwa metode pendidikan adalah semua cara yang digunakan dalam upaya mendidik. Kemudian Abdul Munir Mulkan, mengemukakan bahwa metode Pendidikan adalah suatu cara yang dipergunakan untuk 
menyampaikan atau mentransformasikan isi atau bahan pendidikan kepada anak didik (Mulkhan, A.M., 1993).

Selanjutnya jika kata metode tersebut dikaitkan dengan pendidikan Islam, dapat membawa arti sebagai jalan untuk menanamkan pengetahuan agama pada diri seseorang sehingga dapat terlihat dalam pribadi objek sasaran, yaitu pribadi Islami. Selain itu metode pendidikan Islam dapat diartikan sebagai cara untuk memahami, manggali, dan mengembangkan ajaran Islam, sehingga terus berkembang sesuai dengan perkembangan zaman

\section{Sistem Pendidikan Pondok Pesantren}

Dulu, pusat pendidikan Islam adalah langgar masjid atau rumah sang guru, di mana murid-murid duduk di lantai, menghadapi sang guru, dan belajar mengaji. Waktu mengajar biasanya diberikan pada waktu malam hari biar tidak mengganggu pekerjaan orang tua sehari-hari. Menurut Zuhairini (1997:212), tempat-tempat pendidikan Islam nonformal seperti inilah yang "menjadi embrio terbentuknya sistem pendidikan pondok pesantren." Ini berarti bahwa sistem pendidikan pada pondok pesantren masih hampir sama seperti sistem pendidikan di langgar atau masjid, hanya lebih intensif dan dalam waktu yang lebih lama.

Pendidikan pesantren memiliki dua sistem pengajaran, yaitu sistem sorogan, yang sering disebut sistem individual, dan sistem bandongan atau wetonan yang sering disebut kolektif. Dengan cara sistem sorogan tersebut, setiap murid mendapat kesempatan untuk belajar secara langsung dari kyai atau pembantu kyai. Sistem ini biasanya diberikan dalam pengajian kepada murid-murid yang telah menguasai pembacaan Qurán dan kenyataan merupakan bagian yang paling sulit sebab sistem ini menuntut kesabaran, kerajinan, ketaatan dan disiplin pribadi dari murid. Murid seharusnya sudah paham tingkat sorogan ini sebelum dapat mengikuti pendidikan selanjutnya di pesantren (Dhofier, 1985: 28).

Metode utama sistem pengajaran di lingkungan pesantren ialah sistem bandongan atau wetonan. Dalam sistem ini, sekelompok murid mendengarkan seorang guru yang membaca, menerjemahkan, dan menerangkan buku-buku Islam dalam bahasa Arab. Kelompok kelas dari sistem bandongan ini disebut halaqah yang artinya sekelompok siswa yang belajar dibawah bimbingan seorang guru (Dhofier, 1985: 28). Sistem sorogan juga digunakan di pondok pesantren tetapi biasanya hanya untuk santri baru yang memerlukan bantuan individual.

Pesantren sekarang ini dapat dibedakan kepada dua macam, yaitu pesantren tradisional dan pesantren modern. Sistem pendidikan pesantren tradisional sering disebut sistem salafi. Yaitu sistem yang tetap mempertahankan pengajaran kitab-kitab Islam klasik sebagai inti pendidikan di pesantren. Pondok pesantren modern merupakan sistem 
pendidikan yang berusaha mengintegrasikan secara penuh sistem tradisional dan sistem sekolah formal (seperti madrasah).

Tujuan proses modernisasi pondok pesantren adalah berusaha untuk menyempurnakan sistem pendidikan Islam yang ada di pesantren. Akhir-akhir ini pondok pesantren mempunyai kecenderungan-kecenderungan baru dalam rangka renovasi terhadap sistem yang selama ini dipergunakan. Perubahan-perubahan yang bisa dilihat di pesantren modern termasuk: mulai akrab dengan metodologi ilmiah modern, lebih terbuka atas perkembangan di luar dirinya, diversifikasi program dan kegiatan di pesantren makin terbuka dan luas, dan sudah dapat berfungsi sebagai pusat pengembangan masyarakat (Hasbullah, 1999:155).

\section{Membangun Paradigma Ilmiah dalam Sistem Pendidikan Islam}

Menurut Omar Mohammad al-Toumy al-Syaibany dalam bukunya, Syaibany memaparkan beberapa metode pendidikan, yaitu:

\section{Metode Pengambilan Kesimpulan atau Induktif.}

Metode ini bertujuan untuk membimbing pelajar untuk mengetahui faktafakta dan hukum-hukum umum melalui jalan pengambilan kesimpulan. Metode ini mulai dengan membahas dari bagian-bagian yang kecil untuk sampai kepada undang-undang umum.

Metode ini dapat digunakan pada berbagai ilmu yang mejadi tumpuan perhatian pendidikan Islam. Misalnya, nahu, saraf, fiqhi, hitungan, teknik, fisika, kimia dan dalam berbagai ilmu yang lain. Dan metode ini telah digunakan oleh pendidik-pendidik dan cerdik pandai Islam. Orang-orang Islamlah yang mulamula menggunakan dan memantapkan metode ini sebelum munculnya Roger Bacon, dan sesudah itu Francis Bacon yang selalu dianggap orang sebagai pencipta metode tersebut.

\section{Metode Perbandingan}

Metode ini berbeda dengan metode induktif, dimana perpindahan menurut metode ini dari yang umum kepada yang khusus, dari keseluruhan kepada bagianbagian yang kecil, dimana disebutkan prinsip umum dahulu, kemudian diberi contoh-contoh dan perincian-perincian yang menjelaskan dari prinsip-prinsip umum tersebut. Metode perbandingan dapat digunakan pada pengajaran sains dan pelajaran-pelajaran yang mengandung prinsip-prinsip, hukum-hukum, dan faktafakta umum yang dibawahnya termasuk bagian-bagian dan masalah cabang. Dapat juga dipakai dalam mengajarkan bahasa, baik sastra atau nahu, sejarah, saraf dan lain-lain. 
Pendidik-pendidik dan para ulama-ulama Islam sudah banyak menggunakan metode perbandingan dalam pengajaran, perbincangan dan dalam usaha membuktikan kebenaran fikiran dan kepercayaan mereka pada karyakaryanya. Terutama sesudah mereka berhubungan dengan logika Aristoteles, yang pertama kali merupakan logika perbandingan.

\section{Metode Kuliah}

Metode kuliah adalah metode yang menyatakan bahwa mengajar menyiapkan pelajaran dan kuliahnya, mencatatkan perkara-perkara penting yang ingin dibicarakannya. Ia memulai kuliahnya dengan mengutarakan sepintas lalu tentang perkara-perkara penting yang ingin dibicarakan. Kemudian menjelaskan dengan terperinci tentang perkara-perkara yang disimpulkannya pada permulaan kuliahnya. Pelajar-pelajar mengikuti dengan mendengar dan mencatat apa yang difahami dari kuliah itu, untuk dipelajari sekali lagi dengan cara masing-masing.

Pendidik-pendidik Islam mengenal metode ini, sebagaimana juga mereka telah mengenal dua metode sebelumnya. Mereka menggunakannya dalam pengajaran, bimbingan, dan dakwah kepada jalan Allah. Mereka telah meletakkan dasar-dasar, prinsip-prinsip dan syarat-syarat yang menjamin kejayaannya sebagai metode mengajar dakwah.

\section{Metode Dialog dan Perbincangan}

Metode Dialog adalah metode yang berdasarkan pada dialog, perbincangan melalui tanya jawab untuk sampai kepada fakta yang tidak dapat diragukan, dikeritik dan dibantah lagi. Ahli-ahli pendidikan Islam telah mengenal metode dialog yang dianggap oleh pendidik-pendidik modern berasal dari filosof Yunani Socrates, kemudian mereka kembangkan sesuai dengan tabiat agama dan ahlaknya. Dan atas itulah didasarkan metode perdebatan yang betul-betul merupakan salah satu ciri-ciri khas pendidikan Islam.

\section{Metode Lingkaran}

Pada metode ini, yang terus menerus dipergunakan pada yayasan-yayasan pendidikan dalam dunia Islam semenjak bermulanya dakwah Islamiyah. Pelajarpelajar mengelilingi guru-gurunya dalam setengah bulatan untuk mendengarkan syarahnya. Kalau guru itu duduk, ia duduk bersandar pada sebuah tiang di Mesjid menghadap kiblat. Sebagian ulama mengkhususkan tiang-tiang tertentu yang dijadikan majlisnya sepanjang hidupnya. Kalau seorang guru telah memilih tempat tertentu untuk tempat pengajarannya maka biasanya beliaulah mendapat keutamaan untuk menempati tempat tersebut 
Guru-guru yang memasuki halaqah pelajaran harus telah berwudu' dan berbau harum dan dalam bentuk pakaian yang baik dan dengan khusu' kepada Allah, terutama pada pelajaran tafsir dan hadits. Guru memulai pelajaran dengan membaca Bismillah, dengan memuji kepada Allah dan mengucapkan salawat kepada Nabi SAW. Kemudian barulah dia memulai pelajarannya. Sehingga bila ia selesai ditutupnya dengan membaca al-Fatihah kemudian murid-muridnya disuruh untuk membaca pelajaran yang akan datang.

\section{Metode Riwayat}

Metode ini dianggap salah satu metode dasar yang digunakan oleh pendidik Islam. Hadits, bahasa dan sastera Arab termasuk ilmu-ilmu Islam, dan segi-segi pemikiran Islam yang paling banyak menggunakan metode ini. Tentang hadits Nabi, sahabat-sahabat Nabi SAW meriwayatkan apa yang didengarnya dari beliau tentang hukum-hukum petunjuk, atau pekerjaan-pekerjaan dan keadaan disaksikan dan dilaksanakan.

\section{Metode Mendengar}

Metode ini dilakukan dengan cara mendengarkan sesuatu. Metode ini banyak digunakan pada abad pertama dakwah Islamiyah, karena pada saat itu tulisan dan pembacaan belum tersebar luas dimasyarakat. Dan juga karena para ahli pada abad itu tidak senang menulis apa yang diriwayatkannya sebab kawatir kalau tulisan itu akan serupa dengan al-Qur'an.

\section{Metode Membaca}

Metode ini merupakan alat yang digunakan dalam mengajarkan dan meriwayatkan karya ilmiah yang biasanya bukan karya guru sendiri. Menurut metode ini murid membacakan apa yang dihafalnya kepada gurunya atau orang lain membacanya sedang dia mendengar.

Metode ini tersebar setelah pintu ijtihad didunia Islam telah tertutup, dan pengajaran terbatas hanya pada mengikuti buku-buku tertentu yang berkisar dari situ ke situ saja, tidak boleh melampuinya. Segala usaha hanya tertumpu pada membaca, manghafal dan mengulang-ulang kata-kata orang dahulu.

\section{Metode Imla'}

Metode Imla' adalah metode mencatat apa yang didengarnya. Misalnya seorang guru membacakan sebuah naskah kemudian murid-muridnya mencatat setiap kata yang didengarnya. Metode ini pernah digunakan pada saat 
memberikan imla' dalam hadits seperti yang dilakukan oleh Al-Sayuti pada tahun 873 H. dan metode ini juga digunakan pada pelajaran bahasa Arab.

\section{Metode Hafalan}

Metode hafalan adalah salah satu metode yang terpusat pada hafalan. Ulama-ulama terdahulu banyak yang menggunakan metode ini untuk mengahafal al-Qur'an dan al-Hadits. Karena pada saat itu sedikit sekali yang mengerti tentang tulis menulis. Metode hafalan ini masih digunakan sampai sekarang, karena terbukti bisa meningkatkan pemikiran.

\section{Metode Pemahaman}

Metode pemahaman adalah memahami suatu wacana yang sedang dikaji. Metode ini sangat penting dalam pendidikan Islam, karena dengan memahami sebuah tulisan kita bisa mengerti maksud dibalik tulisan itu. Banyak dari kalangan kita yang hanya membaca sebuah buku tetapi sulit untuk memahaminya. Karena metode ini memerlukan pemikiran yang lebih dibandingkan dengan metode yang lainnya.

\section{Metode Lawatan Untuk Menuntut Ilmu}

Metode lawatan adalah berkunjung kesuatu tempat untuk mencari ilmu atau biasa disebut dengan Studi Banding. Pada saat ini studi banding banyak dipraktekkan dalam lingkungan pendidikan dari TK, SD, SMP, SMA, Perguruan Tinggi, bahkan instansi pemerintah maupun swasta. Hal ini didasarkan pada manfaat yang diperoleh dari metode ini. Dengan metode ini kita akan mempunyai banyak teman, mendapat ilmu, dan memperoleh pengalaman yang sebelumnya tidak kita dapatkan ditempat kita belajar.Para ulama kita pada zaman dahulu banyak yang menggunakan metode ini untuk mencari ilmu, menyebar luaskan Islam.

\section{Penutup}

Paradigma ilmiah system pendidikan islam bias dibangun sebagai system dan sebagai metode:

a. Membangun paradigm ilmiah system pendidikan islam sebagai system input, proses dan out put.

1) Sistem input meliputi sumberdaya yang terlibat dalam pelaksanaan pendidikan pondok pesantren yang mencakup sumber daya manusia serta unsure-unsur yang ada pada pondok pesantren seperti kyai selaku pimpinan, masjid, santri, pondok dan kitab-kitab islam klasik. 
2) Sistem proses sebagai mekanisme pembelajaran yang melibatkan kompetensi organisasi dan manajemen sehingga proses pembelajaran berjalan efektif, efisien dan berkualitas.

3) Sistem output, merupakan keluaran yang diharapkan dan memiliki keunggulankeunggulan kompetitif

b. Membangun paradigm ilmiah system pendidikan islam sebagai metode dalam proses: Pelayanan santri (student service)., Pembelajaran santri (student learning), Pemberdayaan (empowerment), Kemampuan (capacity), Kelembagaan (institutional building).

\section{Daftar Pustaka}

Ahimsa-Putra, H.S. 2008. Paradigma dan Revolusi Ilmu Dalam Antropologi Budaya:Sketsa Beberapa Episode. Pidato Pengukuhan Guru Besar. Yogyakarta; Universitas Gadjah Mada.

Arifin, M. 1987, Filsafat pendidikan Islam, Bina aksara, Jakarta, hal. 97.

Azra, Prof.Dr.Azyumardi, 2001, Pendidikan Islam: Tradisi dan Modernisasi Menuju Milenium Baru, Jakarta: Penerbit Kalimah.

Cuff, E.C. dan G.C.F.Payne (eds.). 1979. Perspectives in Sociology. London: George Allen \& Unwin.

Fasli Jalal, 2001. Reformasi Pendidikan dalam Konteks Otonomi Daerah, Yogyakarta: Adicita.

H.A.R. Tilaar, 1999, Pendidikan, Kebudayaan, dan Masyarakat Madani Indonesia, Strategi Reformasi Pendidikan Nasional, Bandung: Remaja Rosdakarya Offset.

Hasyim, H. Farid., 1998, Visi Pondok Pesantren Dalam Pengembangan SDM: Studi Kasus di Pondok Pesantren Mahasiswa Al-Hikam, UMM, Program Pasca Sarjana, Tesis

Inkeles, A. 1964. What is Sociology? Englewood Cliffs, N.J.: Prentice-Hall.

Kuhn, T. 1970. The Structure of Scientific Revolutions. Chicago: The University of Chicago Press. Second Edition, Enlarged.

Marcus, G.E. dan M.J.Fischer. 1986. Anthropology as Cultural Critique: An Experimental Moment in the Human Sciences. Chicago: The University of Chicago Press. 
Masterman, M. 1970. "The Nature of a Paradigm" dalam Criticism and the Growth of Knowledge, I. Lakatos dan A.Musgrave (eds.). Cambridge: Cambridge University Press.

Mayra Walsh (2002), Pondok Pesantren dan Ajaran Golongan Islam Esaktrim, studi Kasus pada pondok Pesantren Modern Putri 'Darur Ridwan Parangharjo Banyuwangi, ACICIS Program, Fakultas Ilmu Sosial dan Politik, Universitas Muhammadiyah Malang.

Mulkhan, Abdul Munir, 1993, Paradigma Intelektual, SI Press, Yogyakarta.

Nagel, E. 1961. The Structure of Science: Problems in the Logic of Scientific Explanation London: Routledge and Kegan Paul.

Nizar, H. S., 2002, Filsafat Pendidikan Islam, Pendekatan Historis, Teoritis dan Praktis, Ciputat Press, Jakarta.

Omar Mohammad Al-Thoumy Al-Syaibany, 1979, Falsafat Pendidikan Islam, Terjemahan Hasan Lalunggung, Penerbit Bulan Bintang Jakarta, hal 553.

Reynolds, A. 1980. A Primer in Theory Construction.

Sanaky, Hujair, A.H., 2010, Paradigma baru pendidikan Islam sebagai Kerangka Acuan penataan dan Pengembangan pendidikan Islam, Jurnal Pendidikan Islam, Konsep dan Implementasi, $\mathbf{V}: 8$

Tadjab, 1984, Pengantar Filsafat pendidikan Islam, Fakultas Tarbiyah IAIN Sunan Ampel, Surabaya, hal. 39.

Zuhairini, Dra., dll., 1997, Sejarah Pendidikan Islam, Bumi Aksara, Jakarta.

Dhofier, Zamakhsyari, 1985, Tradisi Pesantren: Studi Tentang Pandangan Hidup Kyai, LP3ES, Jakarta.

Hasbullah, Drs., 1999, Sejarah Pendidikan Islam di Indonesia:Lintasan Sejarah Pertumbuhan dan Perkembangan, PT Raja Grafindo Persada, Jakarta, (hl 2427, 138-161) 